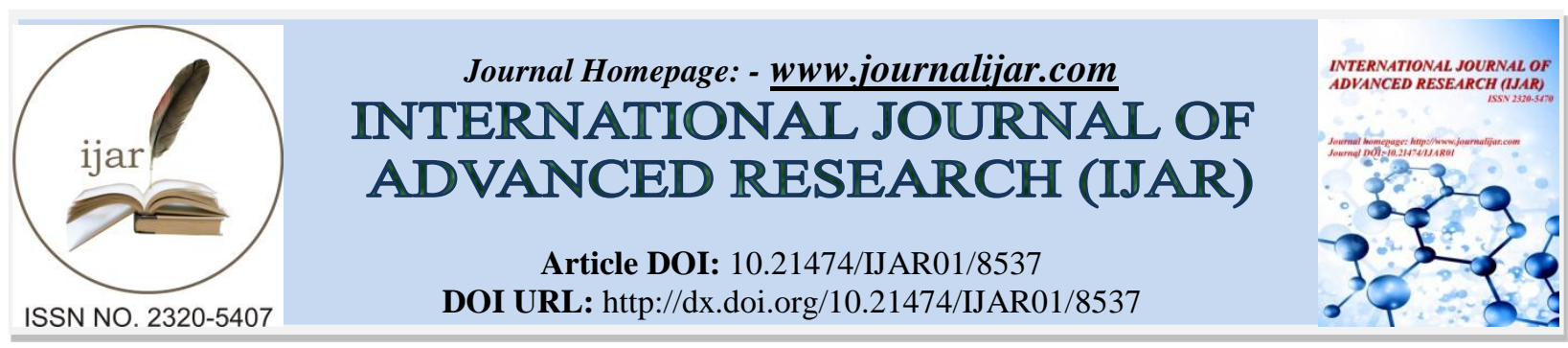

RESEARCH ARTICLE

\title{
PERFORMANCE TRENDS AND LIFECYCLE SAVINGS OF IMPLEMENTED SOLAR PHOTOVOLTAIC SYSTEM IN HOUSING DEVELOPMENT UNDER TROPICAL CLIMAT.
}

\author{
Rawia Marwan Dabdoob ${ }^{1}$ And Puterishireen Jahn Kassim² ${ }^{2}$ \\ 1. Department of Architectural Engineering, Mosul University, Iraq. \\ 2. Department of Architecture, International Islamic University Malaysia, Malaysia.
}

\section{Manuscript Info}

Manuscript History

Received: 11 December 2018

Final Accepted: 13 January 2019

Published: February 2019

Key words:-

Solar photovoltaic system, estimated energy saving, actual energy consumption, lifecycle savings, payback period.

\section{Abstract:}

Along with the green movement in Malaysia, this paper seeks (1) to investigate the performance trends of employed solar photovoltaic system in housing development under tropical climate, (2) to determine the lifecycle savings and payback period of this technology. The research focuses on Mesra Terrace Development which is a Low density housing in Kuala Lumpur, Malaysia as a case study. The research employed a quantitative method for the data collection. The empirical assessment of the after occupancy performance is based on the analysis of energy power as well as savings in both designed and operational phases. The findings indicate that actual energy savings and lifecycle savings have exceeded the estimated values during design phase. Bedsides, the lifecycle saving of the solar photovoltaic system in homes depends so far on the governmental green programs along with the local green industry and market.

Copy Right, IJAR, 2019,. All rights reserved.

\section{Introduction:-}

Malaysia has a tropical climate that enjoys a numerous of renewable energy resources such as solar power [1]. As part of the sustainable movement in the country, programs have been developed via Malaysian government to promote solar technologies applications towards upgrading renewable resources to take place as the fifth resources of fuel in the country [2]. However, it still needs an incentive to upgrade green industry in Malaysia as part of supporting the economic growth of the country [3]. In Malaysia, residential energy power consumption notably increased to $51 \%$ during last ten-year starting from the year 2000. Approximately $26 \%$ of the greenhouse gases are emitted from the residential sector where almost $85 \%$ of this emission is committed during occupancy and operational phase [4]. This, synchronized with the environmental movement, promoted reliance on non-polluting energy resources in housing developments to minimize the environmental impact of $\mathrm{CO} 2$ emission [5]. Accordingly, several implementations of solar power system have been initiated in housing developments in the private sector by ecological developers but without initial authority support. Eventually, Malaysia is viewed as a receiver of green technologies including solar power systems transferred from cold climates European countries that are with different climates. Consequently, they might not work and perform as they were designed. Hereupon, this is considered one of the critical barriers of implementing solar power systems in housing developments in Malaysia it is the lack of post occupancy studies to assess solar PV system performance under tropical climate, and crucially to provide co $\mathrm{mp}$ rehensive data and information about the success and failure after occupancy [6]. Results of simulation models and calculations may not meet the actual performance after occupancy. In addition, another certain barrier of 
implementing solar photovoltaic system is the high initial cost [7]. The effectiveness of savings will influence the payback period or return revenue of an investment. This is usually combined in long term depending on lifecycle saving of the technology [8].

Therefore, this begs these questions: (1) what is the performance trends of the implemented solar photovoltaic system in housing development, (2) what is the lifecycle savings of this technology. These question are to answer two objectives: (1) to investigate the performance trends of employed solar photovoltaic system in housing development under tropical climate, (2) to determine the lifecycle savings and payback period of this technology.

A case study method was employed to investigate the status of this context. The data was conducted from Mesra Terrace Development in Kuala Lumpur. Estimated performance of the implemented solar photovoltaic system is indicated. Furthermore, after occupancy trends of its performance are measured and analyzed in relation with energy saving and lifecycle savings.

This study has significant impact on several social aspects. Initially, the findings imply elevating the quality of living through promoting sustainable lifestyle, and improving environment. Besides, it promotes reaping the financial benefits of integrating the solar photovoltaic.

\section{Solar Photovoltaic System:-}

The solar Photovoltaic system harnesses sunlight directly from the sun and converts it to energy power voltage [9]. At any given point in time, there is about (89petawatts) of available power. In (14.5seconds), the earth receive as much solar energy as humanity consumes in 24 hours. Therefore, solar power is becoming a major contender and a common type of implemented renewable energy systems worldwide [10].

Solar photovoltaic was invented in the 19th century through using selenium and later using silicon cells which are the ones that are used currently [10]. The system consists of photovoltaic panels (PV), inverter, and battery. Basically, photovoltaic panels comprise two layers of cells made largely of silicon wafer arranged into a grid pattern. Since this material is semiconducting, it can be by separating positive charges from negative to generate a current by absorbing sunlight. The photons within photovoltaic cell emit the energy from the sun and impact the electrons which achieve a higher level of potential. At that point, the electrons break free until they reach a diode that allows electrons to pass in only one direction. This process generates congregated electrons flow and hence, electrons creates direct current (DC) [11]. Then, the inverter is responsible for converting the current from direct (DC) to alternating (AC). As part of the system, thermal storage is needed in the system to regulate heat load. Moreover, controller manages pumps work according to heating. Besides, conventional heater preserves the peak hot demands [5]. The generated electricity power is either exported to national electricity grid or stored in battery. In order for photovoltaic panels to function properly and efficiently, they should be designed to meet specifications in size and pitch, and be installed according to the solar cast analysis to capture as much sunlight as possible. Ultimately, this system is usually installed on the top roof of dwellings or on the façades with a slop at towards the direction where the panels are able to capture the sunlight in winter and summer effectively [10]. However, major obstacles of incorporating solar technologies are inefficiency of energy because the system is only effective within daylight hours, expensive cost, difficulty of storing the generated energy power [11]. Even then, the panels must be replaced every few years because the silicon cells decay with use [10].

\section{Promoting Solar Photovoltaic System in Malaysia:-}

The total average monthly solar radiation in Malaysia ranges between $400 \mathrm{MJ} / \mathrm{m} 2$ and $600 \mathrm{MJ} / \mathrm{m} 2$ [12]. Hence, the solar energy system provides $90 \%$ efficiency due to the vertical sunlight at the equator [13].

In 2005, Malaysian Building Integrated Photovoltaic Technology Application Project (MBIPV) was launched in a five-year implementation plan, in order to support solar photovoltaic technology financially in Malaysian market [2]. This green pace suggested SURIA-1000 program in 2007 which broadens the opportunities of the private sector to participate in Building integrated photovoltaic (BIPV) market. The authority sets up related programmes, and regulates policies to conserve natural resources by securing energy supplying, energy exploiting, and limited their environmental impact [14]. The Ministry of Energy, Green Technology and Water has arranged Special Committee on Renewable Energy (SCORE) to encourage renewable energy applications. In 2001, the Malaysian government established Small Renewable Energy Programme (SREP) to promote Renewable energy power production by domestic and industrial sectors. The Sustainable Energy Development Authority Malaysia (SEDA Malaysia) 
launched Feed-in Tariff Programme (FIT) in 2009 to encourage energy industries. This governmental programme allows the developer and homeowner to sell the energy power generated by the implementation of renewable energy resources in domestic and industrial private sectors to Powering the Nation, Tenaga Nasional Berhad (TNB) for high price of revenue returns [15].

\section{Literature Review:-}

Assessing performance of solar PV system is a processed systematical technique of collecting feedback within short or long duration of commissioning in which the building delivers as expected [16]. It helps narrow the existing gap between the actual and predicted performance and evaluates its benefits [17]. Federal Facilities Council (2001) defined such evaluation as "an activity originating in an interest regarding the performance of a building once occupied, and it facilitates performance measurement" [18]. Taylor (2010) quoted Vischer's (2002) definition of after occupancy performance as "how a building performs once it is built, including if and how well it has met expectations and how satisfied building users are with the environment that has been created". Knowledge on the short and long term effects of this technology performance can improve future implementations in homes projects (Communities and local government, 2010). This approach provides significant information and lessons learnt for developer and homeowners who encounter challenges of the risk of litigation by tenants if the solar PV technology perform far from what the homeowners promoted [17].

Many studies and researches have been published on the post-occupancy performance of implemented solar photovoltaic system in housing developments. Aldrich (2012) conducted an occupancy performance study addressing solar photovoltaic power system, which implemented in 20 Platinum level dwellings of Wisdom Way Solar Village in United States. Since the Development depends on solar in providing energy power demands, PV system were integrated on the top roofs of each dwelling and the dwellings were oriented in such a way that the integrated solar panels capture maximum sunlight avoiding acquired shaping from other surrounding dwellings. The results showed actual energy generated by the solar photovoltaic system were slightly higher than the estimated values. Daily average of energy power generated per dwelling was about $1.6 \mathrm{kWh}$. Solar photovoltaic system provides $77 \%$ of energy saving, and this reduces fuel consumption about $83 \%$ [19]. Similar results has been found by Lazarus (2009) who measured energy and lifecycle savings through evaluation of the merged solar photovoltaic system in BedZED Development within the first year of occupation. BedZED development was equipped with 1,138 solar laminates providing $777 \mathrm{~m} 2$ of solar energy captured area. The laminates are placed in two locations on each dwelling according to the solar cast analysis. They were installed on the rooftop sloping at $10^{\circ}$ and $20^{\circ}$ towards the south where panels are able to capture the sunlight in winter and summer effectively. Besides, solar photovoltaic panels were fixed as second floor windows of the southern façade. It was predicted that the system would generate $88,000 \mathrm{kWh}$ annually, which prevents $46,024 \mathrm{~kg}$ of CO2 emission and provides RM33,121.4 (£7,216) of annual revenue returns. Actual measurement showed that solar panels have produced energy power approximately as predicted, where the average of annual generated energy is about $84,426.82 \mathrm{kWh}$. However, the average of annual revenue returns were slightly lower than the predicted ones. They were measured about RM31, 776.57 (£6,923) [20]. The findings of the current study are consistent with those of Hodge (2010) who evaluated the performance of this system in BedZED Development after seven years of occupancy. The results showed actual performance and energy savings exceeded the estimated values. This project achieved actual $45 \%$ energy reduction compared to the level of energy consumption in Sutton while the predicted saving was $33 \%$ [21].

\section{Green Premium Cost and Life-Cycle Savings:-}

Since home is placed at the hierarchy of human needs, it is considered as a significant investment to its owner [11]. Green premium cost refers to the incurred additional cost required in adding solar PV panels in a buildings. It is recovered by revenue returns which obtained during efficient and effective performance of the solar technology [22]. This green premium cost is affected by the governmental green market and industry support. Therefore, it is financially considered one of the barriers that stunts developers and homeowners, from upgrading green investment who seek for quick wins and benefits [7]. On the other hand, lifecycle saving (LCS) of the solar PV system refers to the financial benefits gained from the efficient performance of this technology within its lifetime duration. During occupancy phase of the technology's life span, revenue returns are obtained from operating it where energy consumption is reduced and energy productivity is promoted [21]. Therefore, these revenue returns are known as operational saving. In the long term, green premium cost and maintenance cost of the solar PV technology are recovered by these revenue returns [23]. Hence, the time in which the additional cost is repaid is known as payback period. 


\section{Methodology:-}

A quantitative method is carried out to explore performance and lifecycle savings of the solar photovoltaic system. The technique of collecting data from the case study was confined to in-depth interview with the Developer of Mersa Terrace Development, Mrs. Rosemary M. L. Tan, with duration from 3:45pm to 6:00pm, in Palam Mesra Sdn. Bhd, Desa Sri Hartamas, to complete the quantitative data. Detailed questions was directed to the Developer about performance of the solar photovoltaic system to earn her perception upon it, and to report the needs and determine its benefits and defects after occupancy. The collected data contents cumulative bills of electrical energy consumption of the dwellings and the common area of the case study for five months from November 2012 to March 2013, which was collected from TNB. Besides, electrical energy generated via the solar photovoltaic power system in the development during the first year of occupancy, particularly from October 2009 to October 2010, was collected from the Developer's documents along with TNB bills of FIT programme for nine months from May 2012 to January 2013. These data were analyzed to performance trends of the solar PV system after commission. Furthermore, the capital cost of the development. Based on electricity tariff of TNB in 2013, the cost of energy consumption is determined by converting the energy consumption ( $\mathrm{kWh}$ ) from the conducted electricity bills to Malaysian currency (RM). This conversion is yielded to cumulative method where every $100 \mathrm{kWh}$ is charged by specific tariff. It is worth mentioning that in some calculations, the average of electricity tariff is taken as RM0.38.

\section{Description of the case study; Mesra Terrace Development:-}

Mesra Terrace development is a gated low density housing development located at the end of Dutamas Raya Street in the arising neighborhood of Dutamas, 51200Kuala Lumpur, Malaysia. The construction of the development was completed in 2009. In conjunction with eco-friendly environment, the site was planned to hold 40 dwellings of peculiar communal community with wide central green courtyard. All cars' traffic and parks are designed behind the dwellings to provide healthy environment in the central landscape, as illustrated in Figure 1.

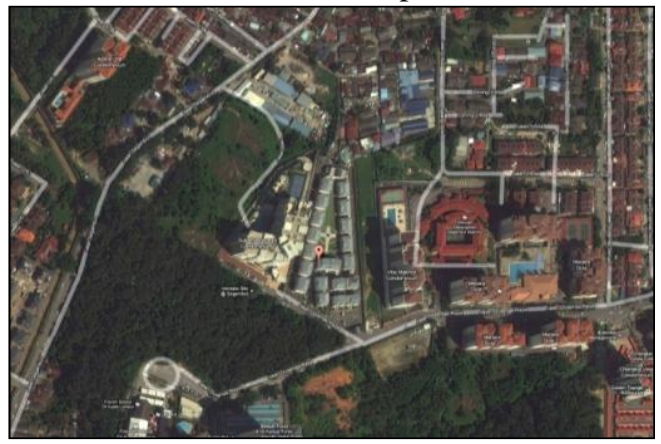

Figure 1:-Location of Mesra Terrace development in Kuala Lumpur

Considerable range of implemented green technologies was integrated in the development. Solar photovoltaic power system is shared in the Development and is installed on the rooftop of the clubhouse hosting 48 solar laminates covering around $130 \mathrm{~m} 2$ of the roof area, as illustrated in Figure 2.

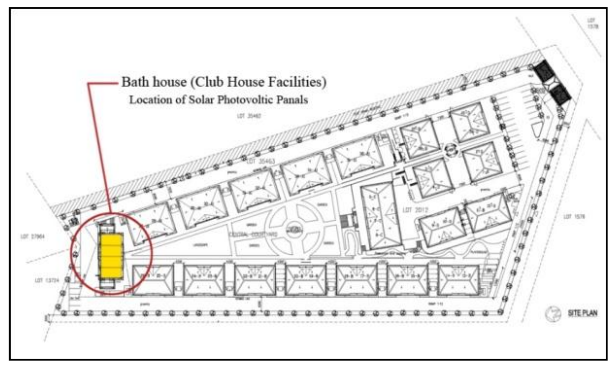

Figure 2:-Roof plan for the club house where solar photovoltaic panels were installed

In respect with Malaysian sun cast, the solar photovoltaic panels were tilted with optimal angle at $10^{\circ}$ perpendicularly oriented to uptake the most sunlight, as indicated in Figure 3. 


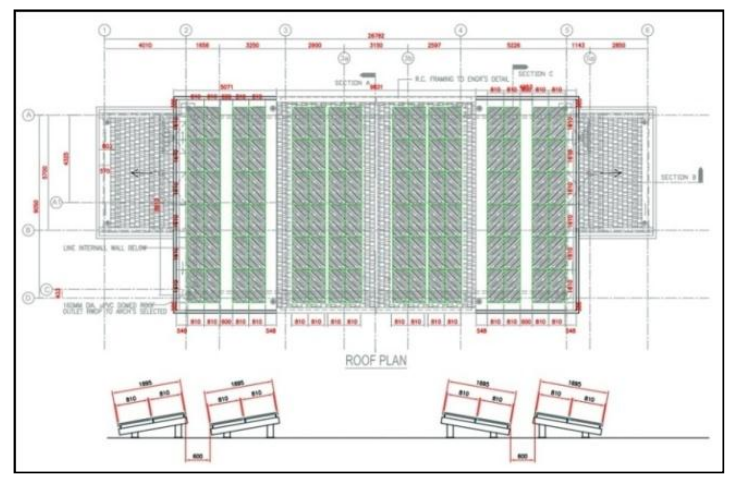

Figure 3:-Roof plan for the club house explaining the tilted of solar photovoltaic panels

Two power inverters are included as an intrinsic part of the solar photovoltaic system that convert the direct current (DC) generated by solar photovoltaic system into alternating current (AC) which is compatible with the transferred power in electrical network. Since, the capacity of the individual solar laminate is $200 \mathrm{~W}$, the peak power generated by the array is $9.6 \mathrm{kWp}$.

\section{Performance and Cost Calculations:-}

The annual effective energy generation by integrated photovoltaic system is estimated by the following calculations: Capacity of $\mathrm{PV} *$ effective sunny hours per day * days with sunlight during the year.

Where: the capacity of PV is $9.6 \mathrm{kWp}$, effective sunny hours per day is 6 hours, and days with sunlight during the year is 168 days.

Lifecycle saving that is gained from implementing the solar photovoltaic system is calculated by

$=($ annual energy saving cost $(\mathrm{RM}) *$ estimated lifetime of the green technology (year) $)-($ green premium cost + Lifecycle cost of maintenance)

Lifecycle cost (LLC) of maintenance is assigned as

$=($ green premium cost $* 15 \%) *$ lifetime of the green technology (year)

The annual energy savings is calculated by converting energy saving in kWh to currency with help of the following formula;

Annual energy savings $(\mathrm{RM})=$ annual energy saving $(\mathrm{kWh}) *$ electricity tariff

Furthermore, payback period is calculated by the following formula,

Payback period (year) = green premium cost $(\mathrm{RM}) /$ Lifecycle saving $(\mathrm{RM})$

\section{Results \& Discussion:-}

The data are analysed and discussed according to the two objectives of the research. Firstly, the performance trends and lifecycle saving of the solar PV system are explored. Secondly, lifecycle savings, and payback period are investigated.

\section{Performance Trends of the Solar PV System in Mesra Terrace Development:-}

In order to explore the performance trends of the solar PV system, firstly, estimated energy saving of the system is determined, secondly, trends in solar photovoltaic system after commissioning is investigated according to the collected data. Then, energy savings assessment is held to evaluate the system performance in the development.

\section{Estimated Energy Saving of the Solar Photovoltaic System:-}

The annual effective energy generation by integrated photovoltaic system is estimated by $9,676.8 \mathrm{kWh}$ per annum for total development that provides RM3,455.99 of revenue returns. Hence, the monthly average of energy production of the system per dwelling is $20.16 \mathrm{kWh}$ that prevents $10.54 \mathrm{~kg}$ of CO2 emission, as indicated in Table 1.

Table 1:-Estimated generated energy by the solar photovoltaic system

\begin{tabular}{|l|l|l|l|}
\hline Period & Energy generated $(\mathrm{kWh})$ & $\mathrm{CO}_{2}$ Emission $(\mathrm{kg} / \mathrm{kW})$ & Revenue Returns $(\mathrm{RM})$ \\
\hline Total Annual & $9,676.80$ & 506.90 & $3,455.99$ \\
\hline Monthly Average & 806.4 & 421.74 & 287.99 \\
\hline Monthly per dwelling & 20.16 & 10.54 & 7.19 \\
\hline
\end{tabular}


Trends in Solar Photovoltaic System after Commissioning:- Based on the collected data, the monthly trends of Actual generated energy power via solar photovoltaic system varied from around $630 \mathrm{kWh}$ and $930 \mathrm{kWh}$, as indicated in Figure 4.

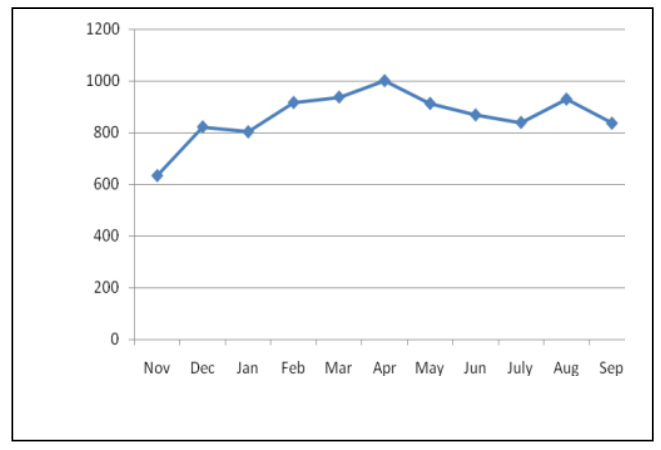

Figure 4:-The trend of energy power generated by SPV in Mesra Terrace

The annualized total energy production power in the Development is measured about $10,507 \mathrm{kWh}$ saving $5495.16 \mathrm{~kg} / \mathrm{kW}$ of $\mathrm{CO}_{2}$ emission, and providing $\mathrm{RM} 3,831.96$ of revenue returns. The monthly average of energy generation per dwelling is about $21.88 \mathrm{kWh}$ that constricted $11.44 \mathrm{~kg}$ of dioxide carbon emissiom. This production of energy has been exported and sold to Powering the Nation, Tenaga Nasional Berhad (TNB) for RM319.33 of annual returns, as indicated in Table 2. Comparatively, the actual performance trends to the solar PV system meets and exceeds the estimations, where actual average of monthly energy production per dwelling is $21.88 \mathrm{kWh}$ and the estimated one is $20.16 \mathrm{kWH}$.

Table 2:-Energy Generated Details

\begin{tabular}{|l|l|l|l|}
\hline Period & Energy generated $(\mathrm{kWh})$ & $\mathrm{CO}_{2}$ emission $(\mathrm{kg} / \mathrm{kW})$ & Revenue Returns $(\mathrm{RM})$ \\
\hline Total Annual & 10,507 & 5495.16 & $3,831.96$ \\
\hline Monthly Average & 875.58 & 457.92 & 319.33 \\
\hline Monthly per dwelling & 21.88 & 11.44 & 7.98 \\
\hline
\end{tabular}

\section{Energy Savings Assessment:-}

The assessment of actual energy power uses and savings of the implemented solar photovoltaic panels in Mesra Terrace Development involves determining productivity of energy by the system to energy consumption in the Development. The energy power is consumed by two main parts in Mesra Terrace development, particularly, the residential dwellings, and the common area consisting of the landscape of the courtyard and the clubhouse which serve the development. The calculated bills of five months energy use of dwellings in Mesra Terrace Development show disparity in energy consumption. The monthly energy usage ranged between $316.5 \mathrm{kWh}$ and $2,150 \mathrm{kWh}$. During the in-depth interview, the Developer mentioned that some dwellings are home office where the occupants live and work at home and use part of the energy to do business online which justifies the additional energy consumption. Moreover, there are various implemented air conditioning differences among dwellings. While some dwellings did not install this system in the rooms, other dwellings implemented 8 air conditioning systems. Based on data collection, the average of actual monthly energy consumption per dwelling is about $915.92 \mathrm{kWh}$ that responses on $479.02 \mathrm{~kg} / \mathrm{kW}$ of $\mathrm{CO}_{2}$ emission, as Table 3 indicates. Accordingly, the total annual average of energy consumption by the dwellings in the development is about $439,641.60 \mathrm{kWh}$, which emits $229,932.40 \mathrm{~kg} / \mathrm{kW}$ of $\mathrm{CO}_{2}$.

Table 3:-Energy consumption in Mesra Terrace dwellings

\begin{tabular}{|l|l|l|l|}
\hline Period & Energy Consumption $(\mathrm{kWh})$ & $\mathrm{CO}_{2}$ emission $(\mathrm{kg} / \mathrm{kW})$ & $\mathrm{Cost}(\mathrm{RM})$ \\
\hline Total Annual & $439,641.60$ & $229,932.40$ & $162,057.60$ \\
\hline Total monthly Average & $36,636.80$ & $229,932.40$ & $13,505.10$ \\
\hline Monthly per dwelling & 915.92 & 479.02 & 337.62 \\
\hline
\end{tabular}

For the common area of Mesra Terrace Development, the energy is consume to light the garden of courtyard landscape and the clubhouse whereby the types of merged lighting are efficient LED lamps and low energy lighting. The actual monthly energy consumption of the collected utility bills of ranged between $1,072 \mathrm{kWh}$ and $2,096 \mathrm{kWh}$. The Developer commented that the garden lights are switched off at mid night, but in March 2012 the bill was 
doubled because the new manager of the Development left the garden lights switched on for additional 7 hours (they were left on from 7:00pm to 7:00am). The average of monthly energy consumption by the common area is measured about $1,454 \mathrm{kWh}$. Hence, the average of annual energy usage is around $17,448 \mathrm{kWh}$ which emits about $9125.30 \mathrm{~kg} / \mathrm{kW}$ of $\mathrm{CO}_{2}$. The monthly energy usage per dwelling is about $36.35 \mathrm{kWh}$, as Table $\mathbf{4}$ determines.

Table 4:-Energy consumption of the common area

\begin{tabular}{|c|c|c|c|}
\hline Period & Energy Consumption (kWh) & $\mathrm{CO}_{2}$ Emission $(\mathrm{kg} / \mathrm{kW})$ & $\begin{array}{l}\text { Cost } \\
\text { (RM) }\end{array}$ \\
\hline Total Annual & 17,448 & 9125.30 & 5,262 \\
\hline Total monthly Average & 1,454 & 760.44 & 438.50 \\
\hline Monthly per dwelling & 36.35 & 19.01 & 10.96 \\
\hline
\end{tabular}

Consequently, the total annual energy consumption by the dwellings and the common area per dwelling in Mesra Terrace Development is about $457089.6 \mathrm{kWh}$. Monthly energy consumption by the dwellings and the common area is measured about $952.27 \mathrm{kWh}$ per dwelling.

The net energy power consumption in the dwellings of Mesra Terrace Development is the result of extracting energy utility (Underwood, 2010). Analytically, monthly energy consumption by the dwellings of the Development is the discrepancy between total energy consumption in the development which includes energy of common area and the household, and energy generated by solar photovoltaic power system in the development. Since the monthly electricity consumption per dwelling and the common area per dwelling is $952.27 \mathrm{kWh}$, and Month electricity production per dwelling is $21.88 \mathrm{kWh}$, the net monthly energy consumption per dwelling in the development is about $930.39 \mathrm{kWh}$, as Table 5 elucidates.

Energy saving is achieved by energy efficient technology. It refers to the percentage of energy reduction to the baseline or conventional energy use (Jones \& Vyas, 2008; Underwood, 2010). Since the estimated Monthly generated energy by the solar photovoltaic system per dwelling is $20.16 \mathrm{kWh}$, and the actual month electricity production per dwelling is about $21.88 \mathrm{kWh}$, actual energy saving percentage of the solar photovoltaic system is about $2.29 \%$, which is exceeds the estimated energy saving that was predicted about $2.11 \%$.

Table 5:-Net energy consumption in Mesra Terrace Development

\begin{tabular}{|l|l|l|l|}
\hline Criteria & $\mathrm{kWh}$ & $\mathrm{CO}_{2}$ & $\mathrm{RM}$ \\
\hline Monthly electricity consumption per dwelling & 915.92 & 479.02 & 319.33 \\
\hline Monthly electricity consumption of the common area per dwelling & 36.35 & 19.01 & 710.96 \\
\hline Month electricity production per dwelling & 21.88 & 11.44 & 7.98 \\
\hline Net monthly energy consumption per dwelling & 930.39 & 486.59 & 344.19 \\
\hline Annual net energy consumption in the Development & $446,587.2$ & $233,565.1$ & $165,211.2$ \\
\hline
\end{tabular}

\section{Lifecycle Savings and payback period:-}

According to the collected data, the total green premium cost of integrating 48 solar photovoltaic panels on the rooftop of the clubhouse is RM131,200. That rates $0.27 \%$ as development cost regarding the total cost of development construction, as shown in Table 6.

Table 6:-The green cost premium of the solar photovoltaic panels

\begin{tabular}{|l|l|l|l|}
\hline Green technology & Description & Details & Development cost \% \\
\hline Solar PV panels & communal & 48 Panel & $0.27 \%$ \\
\hline
\end{tabular}

The Developer of Mesra Terrace Development registered in FIT Programme in 2012, where the generated energy is sold to the TNB. The results indicated that $625.1 \mathrm{kWh}$ monthly generated energy yielded RM1,076.6 monthly average of returns in FIT Programme, whereas it bring back only RM211.25 of returns from TNB without FIT Programme for the same exported energy power, as illustrated in Figure 5. 


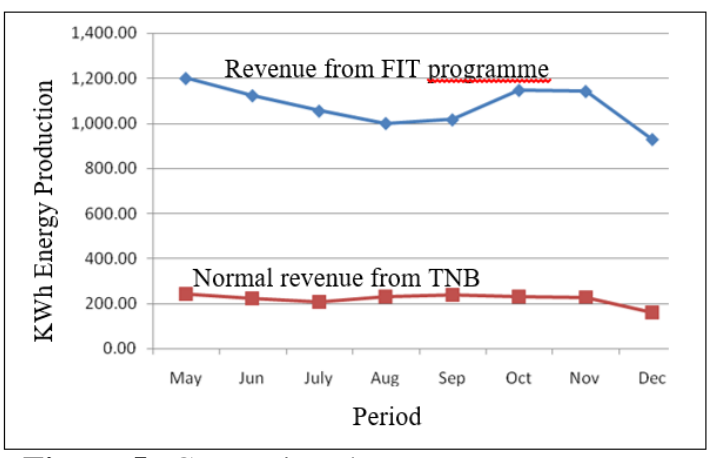

Figure 5:-Comparison between revenue returns

Involving in such governmental programme, FIT Programme, that encourages private energy industries, promotes tremendously the lifecycle savings and paybak period of the solar PV technology due to the high price of revenue returns from the programme that reaches six times the normal returns from TNB out of this Programme.

Hereupon, the total annual gained revenue returns from FIT programme is about RM12,919.20, and hence, the monthly value per dwelling is around RM26.91, as exhibited in Table 7.

Table 7:-Energy generated details and its revenue returns from FIT Programme

\begin{tabular}{|l|l|l|l|}
\hline Period & energy generated $(\mathrm{kWh})$ & $\mathrm{CO}_{2}$ emission $(\mathrm{kg} / \mathrm{kW})$ & Revenue Returns $(\mathrm{RM})$ \\
\hline Total Annual & $7,501.2$ & $3,923.13$ & $12,919.2$ \\
\hline Total monthly Average & 625.1 & 326.92 & $1,076.6$ \\
\hline Monthly per dwelling & 15.62 & 8.17 & 26.91 \\
\hline
\end{tabular}

Solar photovoltaic system has limited operational lifetime which is assumed as 20 years [5], and [9]. It is required about RM19,680 of maintenance cost throughout its lifetime. Hence, the implemented solar PV system in Mesra Terrace Development achieves RM 107,504 as lifecycle savings. Based on that, the payback period of the solar photovoltaic system in Mesra Terrace Development is calculated as one year and three months, as indicated in Table 8 .

Table 8:-Lifecycle saving and payback period

\begin{tabular}{|l|l|l|l|l|l|}
\hline $\begin{array}{l}\text { nnual saving } \\
(\mathrm{RM})\end{array}$ & Lifetime (year) & $\begin{array}{l}\text { Operational } \\
\text { saving (RM) }\end{array}$ & $\begin{array}{l}\text { Maintenance } \\
\text { cost (RM) }\end{array}$ & LCS (RM) & $\begin{array}{l}\text { Payback period } \\
\text { (year) }\end{array}$ \\
\hline $12,919.2$ & 20 & 258,384 & 19,680 & 107,504 & $\begin{array}{l}\text { One year and } \\
\text { three months }\end{array}$ \\
\hline
\end{tabular}

\section{Conclusions:-}

The actual performance trends of the solar PV system under tropical climate meets the predictions of energy savings. Besides, the lifecycle savings exceeds the expectations since the Malaysian government support the green attempts of the privet sector in implementing renewable technologies in homes and sell the energy generated to the local net. However, the lack of institutional green support in Malaysia has stunted the green industry. Although Malaysia is dedicated to global environmental concerns, there are limited initiatives to integrate renewable energy technologies such as solar power in housing developments. Several implementations have been initiated in the private sector by ecological developers without authority support. Despite of the annual domestic investment of RM56,087 million, there is no dedicated financial funding to support sustainable housing developments. Besides, based on the provided green knowledge, and information of the green premium cost of solar power systems, the integration of this technology in a home must be folded into the cost, and hence, offering affordability level of each home to its buyers. In addition, Ecological awareness is considered at the crux of the sustainable strategy. Raising ecological awareness of general public has contributively part in driving environmental movement in which people in different strata of community realize their roles in supplementing sustainable development. In addition, it is critical to develop evaluation approach to measure building performance specifically under tropical climate. This approach should be designed experientially to be appropriate with local measurements involving local social, economic, and environmental variables in Malaysia. 


\section{Acknowledgement:-}

The authors would like to thank the Developer of Mesra Terrace Development for the support giving information about the case study.

\section{References:-}

1. N. A. Omar, M. S. Ahmad, H. R. Siddiquei, and S. M. Nor, "Renewable energy in Malaysia: strategies and development." Environmental management and sustainable development, 2(1), 51-66, 2013.

2. L. C. Haw E. Salleh, and P. Jones, "Renewable Energy Policy and Initiatives in Malaysia." ALAM CIPTA, Intl. J. on Sustainable Tropical Design Research \& Practice, 1 (1), 33-40, 2006.

3. P. S. J. Kassim, Ali, N. A. Ariffin, and R. M. Dabdoob, "Features, Green Premium Costs And Operational Savings of Sustainable Medium Density Homes - A Focus on International and Malaysian Case Studies." Conference on Affordable Quality Housing 2013, Putrajaya, 2013.

4. N. S. M. Zaid, "Measuring electricity-elated GHG emissions and he affordability in Malaysia low-cost housing: A case study of low-cost housing projects in Kuala Lumpur." PhD Thesis, UNSW, 2013.

5. A. D. Miller, "Energy Production and Alternative Energy." Gale, Cengage Learning, New York, 2011.

6. M. Samari, N. Ghodrati, R. Esmaeilifar, P. Olfat, and M. W. Shafiei, "The investigation of the barriers in developing green building in Malaysia." Modern applied science: Published by Canadian center of science and education 13 (7) 2, 1-12, 2013.

7. R. Rovers, "Sustainable housing projects: implementing a conceptual approach. Amsterdam." Techne press, 2008.

8. J. Braman, and M. James, "Greening our built world: Costs, benefits, and strategies." Green Kats. Island Press, Washington, Covelo, London, 2010

9. A. Friedman, "Sustainable residential development: Planning and design for green neighborhoods." Mc Graw Hill, 2007.

10. P. Harrington A. Brill J. Kew, and D. Harney, "Solar Energy, An e-book on strategies for sustainability" authored by the Class of 2012 Massachusetts Academy of Mathematics and Science, 2012.

11. L. Underwood, "The green home: A decision making guide for owners and builders: Delmar Cengage Learning." USA, 2010

12. S. Mekhilef, "Renewable energy resources and technologies practice in Malaysia." 5th International symposium on hydrocarbons \& chemistry (ISHC5), Sidi Fredj, Algiers, May the 23rd to 25th, 2010.

13. A. Y. Abdulla, "A measurement and verification." Report presented to Palam Mesra Sdn. Bhd. Prepared by environmental analysis group, Kulliyyah of architecture \& environmental design, International Islamic University Malaysia, Kuala Lumpur, 2011.

14. M. R. Islam, N. A. Saidur, Rahim, and K. H. Solangi, "Renewable energy research in Malaysia." Engineering etransaction (4)2, 69-72, 2009.

15. Sustainable Energy Development Authority Malaysia, "Renewable energy development and feed-in tariff (fit) implementation in Malaysia: Information and training session on European Union framework programme 7 for research and technological development." Sustainable energy development authority Malaysia, 2012.

16. N. B. Huat, and Z. A. Akasha, "Building performance analysis model using post occupancy evaluation for energyefficient building in Malaysia." National Postgraduate Conference (NPC), Kuala Lumpur, 19-20 Sept, pp 1-7, 2011.

17. T. Taylor, J. Littlewood, A. Geens, J. Counsell, and G. Pettifor, "Developing post-occupancy evaluation techniques for assessing the environmental performance of apartment buildings in Wales: An ecological perspective." UK. 9th International Detail design in architecture conference. Innovative detailing: Materials \& construction methods for a low carbon future. 4-5 November 2010, University of Central Lancashire, Preston, 2010.

18. Z. Gill, Tierney, J. Michael, Pegg, M. Ian, and N. Allan, "Low-energy dwellings: The contribution of behaviours to actual performance." Building Research and Information, 38:5, 491-508, 2010.

19. R. Aldrich, "Wisdom way solar village: Design, construction, and analysis of a low-energy community." Building America Best U.S. department of energy, 2012.

20. N. Lazarus, "BedZED: Toolkit Part II A practical guide to producing affordable carbon neutral developments." BioRegional solutions for sustainability, 2009.

21. J. Hodge, "BedZED seven years on The impact of the UK's best known eco-village and its residents." BioRegional development group, BedZED centre, 24 Helios Road, Wallington, Surrey SM6 7BZ, UK, 2009.

22. Y. Phillips, "Landlords versus tenants: Information asymmetry and mismatched preferences for home energy efficiency." Energy Policy, 45, 112-121,2012.

23. E. Bloustein, "Green residential home study: A shore community in New Jersey." Rutgers center for green building, New Brunswick, NJ, 2011. 